УДК 341.1/8:351.791.2

https://doi.org/10.52058/2708-7530-2022-1(19)-254-266

Гаверський Віталій Валерійович кандидат юридичних наук, доцент кафедри морського та митного права, Національний університет «Одеська юридична академія», вул. Академічна, 2, м. Одеса, 65009, тел.: (048) 719-88-12, https://orcid.org/0000-0002-6229-1275

Серафімов Віталій Віталійович кандидат юридичних наук, доцент, директор, ТОВ «Китайський юридичний центр в Одесі», вул. академіка Філатова, 70, корпус 1, м. Одеса, 65074, https://orcid.org/0000-0002-0436-2071

\title{
ПРАВОВІ СТАНДАРТИ ПУБЛІЧНОГО АДМІНІСТРУВАННЯ РЕЖИМУ СУДНОПЛАВНИХ РІК
}

Анотація. Досліджується система правових стандартів адміністрування режимів судноплавних рік. Відзначається, що міжнародними визнаються ріки, які перетинають територію двох або більшої кількості держав та виступають предметом їх міжнародно-правових відносин. Перетинання або поділ міжнародною рікою території декількох держав створює систему взаємозв'язків їх інтересів. Це, у свою чергу, зумовлює взаємні права та обов'язки стосовно цієї ріки, їі правового режиму. Загальним правовим та організаційним базисом тут виступає правило про те, що прибережні держави мають використовувати води ріки лише таким чином, щоб не порушити інтересів інших прибережних держав, також вони мають рівні права щодо використання iї вод. Охарактеризовано норми конвенцій і статутів про судноплавні водні шляхи, що мають міжнародне значення та про режим транзиту. Зауважено, що сучасне публічне адміністрування режиму судноплавних рік формується на підставі правових стандартів різного рівня, «виходить» за межі державних кордонів, базуючись на всесвітніх та регіональних міждержавних угодах, i національному законодавстві. Інституційний механізм такого адміністрування не обмежується національними органами публічної адміністрації, а охоплює наддержавні інституції - річкові комісії. Правові стандарти такого адміністрування втілено у блоці угод, що присвячено окремим річковим комунікаціям, та сконцентровано на основних, найбільш вагомих, його аспектах. Виокремлено та охарактеризовано стандарти публічного адміністрування режиму судноплавних рік: взаємність, рівність, надання національного режиму для суден договірних сторін, забезпечення безпеки судноплавства, закріплення територіального верховенства (суверенітету) на відповідні ділянки водної комунікації за прибережними державами; заборона (або обмеження) плавання військових кораблів неприбережних країн та суден, що мають військові цілі, 
встановлення дозвільного порядку проходження військових суден прибережних країн чужими ділянками комунікації; забезпечення свободи торговельного судноплавства; співробітництва держав; забезпечення свободи транзиту.

Ключові слова: внутрішні води держави, судноплавні ріки, міжнародні ріки, стандарти, публічне адміністрування, публічне управління, внутрішній водний транспорт, внутрішні водні шляхи.

Gaverskyi Vitalii Valeriiovych $\mathrm{PhD}$ in Law, Associate Professor of the Department of Maritime and Customs Law, National University "Odesa Law Academy”, Akademichna St., 2, Odessa, 65009, tel.: (048) 719-88-12, https://orcid.org/0000-0002-6229-1275

Serafimov Vitali Vitaliiovych $\mathrm{PhD}$ in Law, Associate Professor, Director of Chinese Law Center in Odessa, Academician Filatov St., 70, 1, Odessa, 65074, https://orcid.org/0000-0002-0436-2071

\section{THE LEGAL STANDARDS OF PUBLIC ADMINISTRATION OF THE REGIME OF NAVIGABLE RIVERS}

Abstract. The system of legal standards of administration of the regimes of navigable rivers is researched in the article. It is noted that rivers are recognized international that cross the territory of two or more states and are the subject of their international legal relations. Crossing or dividing of the international river of the territory of several states creates a system of relationships of their interests. This, in turn, determines the mutual rights and obligations of this river, its legal regime. The general legal and organizational basis is the rule that the riverside states should use the waters of the river only in such a way as do not violate the interests of other riverside states, and they also have equal rights to use its waters. The norms of the conventions and the statutes on navigable waterways of international importance and the transit regime have been described. It has been noted that the modern public administration of the regime of navigable rivers is formed on the basis of legal standards of different levels, "goes" beyond the state borders, based on the world and the regional interstate agreements and the national legislation. The institutional mechanism of such administration is not limited to the national bodies of public administration, but covers the superpower institutions - the river commissions. The legal standards of such administration have been implemented in the block of agreements devoted to separate river communications, and concentrated on the main, most significant, aspects of it. The standards of public administration of the regime of navigable rivers have been distinguished and characterized: reciprocity, equality, assignment of the national regime for ships of contracting parties, ensuring the safety of shipping, consolidation of territorial supremacy (sovereignty) to the relevant areas of water communication in riverside states; prohibition (or restriction) 
of sailing of warships of unriverside countries and ships with military purposes, establishing a permissive procedure for the passage of military ships of riverside countries by foreign areas of communication; ensuring the freedom of trade shipping; cooperation of states; ensuring the freedom of transit.

Keywords: inland waters of a state, navigable rivers, international rivers, standards, public administration, public management, inland water transport, inland waterways.

Постановка проблеми. Наприкінці жовтня 2021 року Україна стала першою країною - не членом СС, яка взяла на себе головування у Стратегії Євросоюзу для Дунайського регіону. Ця Стратегія є платформою і планом дій співпраці 14 країн, що взаємодіють у сферах судноплавства та охорони навколишнього середовища. Українська частина Стратегії охоплює Одеську, Івано-Франківську, Чернівецьку та Закарпатську області [1]. А у грудні 2020 року Україна очолила Дунайську комісію (уперше за 70 років членства) [2]. Дунайська Комісія - міжнародна міжурядова організація, заснована відповідно до Конвенції про режим судноплавства на Дунаї (м. Бєлград, 1948 p. [3]) - фактично стала нащадком середньовічних європейських річкових комісій, що керували судноплавством та іншими аспектами використання рік регіону. Основними цілями ії діяльності $є$ забезпечення та розвиток вільного судноплавства на Дунаї для торговельних суден під прапорами усіх держав відповідно до інтересів та суверенних прав держав-учасниць Бєлградської конвенції, а також зміцнення та розвиток економічних та культурних зв'язків цих держав між собою та 3 іншими країнами [4]. Ці події актуалізували дослідження правових стандартів публічного адміністрування у галузі річкового права, або права внутрішніх водних комунікацій. Її підвищенню також посприяло підписання Угоди про асоціацію з СС у 2014 році [5] та прийняття Закону України від 3 грудня 2020 р. «Про внутрішній водний транспорт» [6].

Аналіз останніх досліджень і публікацій. Наукові правничі дослідження публічного адміністрування режиму судноплавних рік на теперішній час $є$ фрагментарними в Україні. Лише у публікаціях С. Кузнецова та В. Слатвінської, Г. Мошак (щодо імплементації європейських стандартів адміністрування діяльності на ріках в українське законодавство та визначення концептуальних засад його оновлення), Є. Самойленка (в аспекті міжнародноправового регулювання навігаційного використання міжнародних рік), А. Кулько (щодо міжнародно-правового регулювання використання та охорони транскордонних прісних вод) i деяких інших започатковано їх грунтовне висвітлення. Але у розробках зазначених авторів проблематика, пов'язана 3 визначенням системи правових стандартів адміністрування режимів судноплавних рік, комплексно не розглядається.

Мета статті - дослідження системи правових стандартів публічного адміністрування режиму судноплавних рік. 
Виклад основного матеріалу. Правовий режим рік зазвичай визначається національним законодавством, яке відносить їх до складу внутрішніх вод держави. Зокрема, у Законі України від 4 листопада 1991 р. «Про державний кордон України» [7] зазначається, що до внутрішніх вод України належать, крім іншого, обмежена лінією державного кордону частина ... вод річок, озер та інших водойм, береги яких належать Україні (ст. 6). При цьому, великі судноплавні ріки зазвичай перетинають території двох або більше держав, мають міжнародний характер та історично представляють інтерес 3 точки зору права, головним чином в аспекті публічного адміністрування судноплавства.

Раніше вважалося, що міжнародною може вважатися ріка, яка має безпосереднє сполучення 3 морем та використовується для міжнародного судноплавства. На теперішній час підхід до визначення міжнародного характеру ріки під кутом зору судноплавства $є$ дещо застарілим, оскільки багатонаціональні або транскордонні ріки використовуються, головним чином, як джерело водопостачання, для різноманітних промислових цілей, сільськогосподарського зрошення, виробництва електроенергії. Сьогодні міжнародними визнаються ріки, які перетинають територію двох або більшої кількості держав та виступають предметом їх міжнародно-правових відносин. Перетинання або поділ міжнародною рікою території декількох держав створює систему взаємозв'язків їх інтересів. Це, у свою чергу, зумовлює взаємні права та обов'язки стосовно цієї ріки, сумісного визначення іiі правового режиму.

Загальним правовим та організаційним базисом тут виступає правило про те, що прибережні держави мають використовувати води ріки лише таким чином, щоб не порушити інтересів інших прибережних держав, також вони мають рівні права щодо використання її вод. У ст. 1 Бєлградської конвенції 1948 року також підкреслюється, що «навігація на Дунаї повинна бути вільною і відкритою для громадян, торгових суден і товарів усіх держав на основі рівності щодо портових і навігаційних зборів та умов торговельного судноплавства». Отже, тут репрезентовано принцип рівності усіх держав, як прибережних, так й неприбережних щодо використання акваторії міжнародної ріки. Але, зважаючи на особливу небезпеку військових кораблів, зазвичай у міжнародних угодах спеціально обмовляється заборона плавання таких кораблів неприбережних країн та повідомний порядок для військових кораблів прибережних держав.

Принцип рівності зумовлює поділ міжнародних рік на відкриті для міжнародного судноплавства, які зазвичай перетинають території кількох держав, і прикордонні ріки, які, зазвичай, поділяють території кількох держав. Проте ця класифікація, звичайно, є умовною, оскільки одна й та сама ріка може на одній ділянці перетинати території кількох країн, але в іншому - їх розділяти. Також режим міжнародного судноплавства може існувати на прикордонній річці і бути відсутнім на річці, що перетинає території кількох 
держав. Але у всіх випадках ці ріки цілковито обгрунтовано можуть бути визнані міжнародними, бо навіть за відсутності міжнародного договору прибережні держави пов'язані певними правами та обов’язками щодо будьякого їх використання.

Необхідно відзначити, що режим судноплавства такими ріками встановлюється прибережними державами. Лише прибережні держави мають право на те, щоб судна під їх прапорами проходили через річкові води, які належать до складу території іншої прибережної держави, i то на підставі угоди, укладеної між прибережними країнами та відповідно до іï умов. Водночас на користь своєї торгівлі прибережні держави часто надають свободу судноплавства для торговельних суден усіх країн. Однак це їх право, але не обов'язок. Тому судна неприбережних країн зазвичай не мають права проходження міжнародними ріками, якщо інше не встановлено у міжнародному договорі.

Питання використання річкових вод можуть бути урегульовані угодами прибережних держав, а іноді й інших зацікавлених держав зазвичай на локальній (регіональній) основі. Режим найбільш великих та важливих засобів сполучення міжнародних рік регулюються багатосторонніми конвенціями (р. Дунай, р. Рейн). Крім того, ще у 1921 році було укладено Конвенцію та Статут про судноплавні водні шляхи, що мають міжнародне значення [8]. Документ стосується внутрішніх водних шляхів, які у своєму природно судноплавному стані поділяють або перетинають території різних держав. Конвенція стосується також тих водних шляхів, щодо яких або у міжнародних угодах, або у постановах відповідних держав міститься вказівка про її застосування. Згідно зі ст. 3 Статуту, кожна 3 договірних держав зобов'язувалася надати свободу судноплавства суднам інших договірних держав на ділянках водних шляхів міжнародного значення, що перебувають під іï суверенітетом або управлінням. Передбачалося, що при здійсненні судноплавства громадяни, власність і судна під прапорами усіх держав-учасниць Конвенції та Статуту повинні користуватися режимом, базованим на повній рівності. Уніфікувалися права та обов'язки держав стосовно підтримання та поліпшення судноплавних водних шляхів, стягнення зборів, здійснення транзитних i каботажних перевезень, вирішення спорів та ін. Відповідно до Додаткового факультативного протоколу до Конвенції та Статуту, держави, що їх підписали, зобов'язувалися надавати одна одній на основі взаємності свободу судноплавства під час миру також на всіх національних судноплавних водних шляхах або на судноплавних водних шляхах, що не мають міжнародного значення, але є доступними для звичайного торговельного судноплавства до моря та від моря. Документ є діючим до теперішнього часу, проте не загальновизнаним, а на противагу ньому було укладено у 1948 році Бєлградську конвенцію про режим судноплавства на Дунаї.

Угода про асоціацію України та ЄС містить окрему статтю (414), присвячену співробітництву сторін на Дунаї, а у ст. 136 підтверджує, що 
положення існуючих двосторонніх угод у сфері внутрішнього водного транспорту і які не будуть охоплюватися можливими у майбутньому угодами, продовжать застосовуватися. Україною на теперішній час укладено три угоди про судноплавство на внутрішніх водних шляхах: 3 Хорватією [9], Німеччиною [10] та Білоруссю [11]. У них визначено, що судна договірних сторін під час плавання внутрішніми водними шляхами можуть зупинятися у будь-який час доби в їхніх портах та інших офіційно дозволених місцях стоянок на шляху слідування судна (ч. 2 ст. 6 Угоди з Хорватією, ст. 13 Угоди 3 Німеччиною, ст. 8 Угоди 3 Білоруссю). Окремо зазначається, що під час судноплавства Дунаєм також ураховуються норми Бєлградської конвенції 1948 року.

Ці угоди також містять окремі норми, присвячені публічному адмініструванню режиму судноплавства, здійснення адміністративних формальностей і визнання документів моряків: ст. 4 Угоди з Хорватією, ст.ст. 4 - 9 Угоди з Німеччиною, ст.ст. 3 - 9 Угоди з Білоруссю.

Зокрема, відповідно до ст. 4 Угоди з Хорватією, судна та інші плавучі об'єкти однієї сторони після прибуття у внутрішні води іншої сторони або вибуття 3 них зобов'язані пройти прикордонний, митний та інші види контролю в одному з портів, відкритих для заходу іноземних суден. Судна, що входять у порти лише для поповнення суднових запасів (продуктів харчування, питної води, паливно-мастильних матеріалів) або через надзвичайні обставини, мають право на отримання такого самого режиму проведення митних формальностей, як і національні судна, що беруть участь у міжнародному судноплавстві. Кожна зі сторін надає суднам іншої сторони такий самий режим, який вона надає своїм суднам щодо використання місць якірної стоянки, заходження до портів і використання портових споруд та обладнання для навантаження i розвантаження суден, посадки i висадки пасажирів, забезпечення суден водою та продуктами харчування, надання необхідної медичної допомоги, сплати навігаційних (маячних, шлюзових, канальних), портових (якірних, причальних, корабельних) та інших зборів, послуг (лоцманське проведення, буксирування, швартові операціi) та виконання формальностей, пов'язаних з судноплавством. Таким чином, на взаємній основі запроваджено національний режим для суден договірних сторін.

При цьому також передбачається, що органи нагляду на внутрішніх водних шляхах мають право перевірки i контролю 3 метою перевірки дотриманням ними своїх національних норм i правил, що забезпечують безпеку судноплавства, пожежну і екологічну безпеку, а також дотримання положень міжнародних конвенцій, що стосуються режиму безпеки судноплавства, у т.ч. щодо конструкції і спорядження суден, комплектації і кваліфікації екіпажів суден, пожежної та екологічної безпеки. Цим підтверджуються повноваження держав на здійснення контрольних (наглядових) повноважень у сфері забезпечення безпеки судноплавства. 
Необхідно відзначити, що забезпечення безпеки є головним принципом, що скеровує усі нормотворчі процеси у сфері транспорту та є створенням необхідних умов (технічних, експлуатаційних, навігаційних, правових тощо) для надійного існування стану максимальної захищеності людського життя $\mathrm{i}$ здоров'я, майна i навколишнього середовища у процесі експлуатації транспорту або у зв'язку з нею, а також неприпустимості ризику, який може призвести до загибелі або травмування людей, матеріальних збитків або до негативного впливу на навколишнє середовище $[12$, с. 5,160$]$. Це визначення, надане у прив'язці до мореплавства, $є$ цілковито справедливим й для судноплавства річковими комунікаціями. Звісно, тут ризики $\epsilon$ набагато меншими, ніж у непередбачуваному та значно більшому за розмірами та глибинами морському середовищі, проте вони не є менш значущими. Аварії на ріках іноді стають дуже драматичними, як, наприклад, катастрофа судна «Булгарія» - найбільша у новітній історії річкового судноплавства трагедія, що сталася 10 липня 2011 р. у Куйбишевському водосховищі (р. Волга). Тоді загинуло 122 пасажири та члени екіпажу [13]. Відповідно до Звіту Морської адміністрації України «Стан безпеки судноплавства та аварійності на водному транспорті в Україні (у т.ч. і за їі межами, але із українськими суднами), включаючи маломірні (малі) судна, за перше півріччя 2021 року 3 наростаючим підсумком», упродовж 1-го півріччя 2021 року на річковому транспорті сталося 12 аварійних подій без загиблих та зниклих безвісти, проте було травмовано 1 особу (у 2020 році відбулося 6 подій, також без загиблих, зниклих безвісти та травмованих) [14, с. 5]. Причинами аварій було визнано порушення капітанами суден та судновласниками вимог Правил судноплавства на внутрішніх водних шляхах України, затверджених наказом Міністерства транспорту України від 16 лютого 2004 р. № 91 [15], та Положення про порядок видачі посвідчення судноводія торговельного судна, яке допущено до плавання судноплавними річковими внутрішніми водними шляхами, затвердженого наказом Міністерства інфраструктури України від 07 жовтня 2014 р. № 490 [16], щодо здійснення плавання річковими внутрішніми водними шляхами без державного річкового лоцмана за відсутності на судні відповідного кваліфікованого екіпажу для забезпечення безпеки осіб, які перебувають на борту, а також безпеки плавання внутрішніми водними шляхами $[14$, c. 8$]$.

Фактично, за відсутності на теперішній час загальнопідтримуваної міжнародної угоди про принципи управління судноплавством на міжнародних ріках, їх правовий режим тощо, договори, присвячені окремим комунікаціям або двосторонні угоди у договірному порядку сформували такі принципи. Їх важливість та необхідність підтверджується у дослідницькій літературі та підкреслюється, що для ефективної взаємодії держав у сфері судноплавства міжнародними ріками необхідно застосування ними комплексу єдиних принципів правового регулювання судноплавства на міжнародних ріках [17, с. 187]. B.M. Гуцуляк відзначає, що загальними міжнародно-правовими основами 
регулювання режиму міжнародних рік мають бути принципи суверенної рівності сторін, взаємної вигоди, усебічного врахування взаємних інтересів у використанні вод ріки [18, с. 546].

У літературі зазначається про ряд загальних принципів, що містяться у більшості міжнародних інструментів, присвячених правовому регулювання режиму міжнародних рік:

- закріплення територіального верховенства (суверенітету) на відповідні ділянки водної комунікації за прибережними державами;

- заборона (або обмеження) плавання військових кораблів неприбережних країн та суден, що мають військові цілі, встановлення дозвільного порядку проходження військових суден прибережних країн чужими ділянками комунікації;

- забезпечення свободи торговельного судноплавства, що поєднує заходження суден до іноземних портів, здійснення вантажних та інших комерційних операцій, можливість їх бункерувального та технічного обслуговування на рівноправній основі: неухильне виконання судновласниками та операторами суден тарифних, навігаційних, екологічних та інших правил, встановлених прибережною державою [19, с. 131]; також до неї можна зарахувати свободу плавання всією судноплавною частиною ріки, свободу перевезення пасажирів з відкритого моря і у зворотному напрямку між портами різних держав; іiі може бути обмежено лише стосовно військових кораблів.

Дійсно, виходячи із принципу суверенітету держави на внутрішні водні шляхи або їхні ділянки, що входять до складу їі території, держави самостійно вирішують питання про дозвіл або заборону доступу на них іноземних суден. А оскільки ріки, що пересікають або розділяють території двох або декількох держав, є природним засобом сполучення та забезпечення виходу до моря, держави здавна були зацікавлені у договірному регулюванні міжнародного судноплавства такими ріками, а саме в закріпленні необмеженого у часі права проходження суден прибережних та інших держав, а також певного об'єму прав на участь у перевезеннях [20, с. 55]. При цьому, слід пам'ятати, що особливість правового регулювання таких водних комунікацій обумовлена тим, що вони є єдиним природним комплексом (гідрографічний басейн, система водотоку) [21, с. 160] i невипадково, що питання їх охорони унормовано у ряді міжнародних угод. До їх кола належать: Гельсінські правила використання вод міжнародних рік 1966 року, Конвенція з охорони та використання транскордонних водотоків i міжнародних озер 1992 року, Конвенція про право несудноплавних видів використання міжнародних водотоків 1997 року. Значення цієї групи документів є доволі великим, проте вони мають рекомендаційний характер, не містять механізму вирішення міжнародних спорів, а їхній правовий статус не призводить до виникнення у країн-учасниць юридичних зобов'язань. При цьому, у них містяться окремі норми, присвячені публічному адмініструванню діяльності на ріках. Так, 
Гельсінські правила 1966 року [22] передбачають, що прибережна держава здійснює поліцейські права на ділянках ріки або озера, які підпадають під іiі юрисдикцію, зараховуючи, зокрема, захист громадської безпеки і здоров’я населення, причому здійснення цього права не має без достатніх підстав перешкоджати свободі судноплавства (ст. XV), кожна прибережна держава може обмежувати або забороняти перевезення іноземними суднами товарів $\mathrm{i}$ пасажирів у межах своєї території (ст. XVI), надавати неприбережним державам право плавання ріками та озерами у межах іiі території (ст. XVII), прибережні держави зобов'язані також підтримувати в належному порядку ті частини рік чи озер, які перебувають під їхньою юрисдикцією (ст. XVIII). Ці норми слід визнати стандартами (принципами) публічного адміністрування режиму судноплавних рік.

До кола таких принципів, на наше переконання, можна також додати принципи:

- співробітництва прибережних держав, що проявляється, серед іншого, у створенні річкових комісій для вироблення механізмів адміністрування діяльності на ріках, співробітництві таких комісій з іншими зацікавленими державними та наддержавними інституціями тощо, та

- принцип свободи транзиту, відповідно до якого, наприклад, за нормами Бєлградської конвенції 1948 року, на р. Дунай жодні збори за транзит як такий з суден, плотів, пасажирів і товарів установлюватись не будуть (ст. 42), а при проходженні транзитних вантажів через ділянки, де обидва береги Дунаю належать одній і тій самій державі, ця держава має право опечатувати або брати під охорону митного нагляду транзитний товар. При цьому дана держава має право вимагати від капітана чи судновласника письмової декларації лише про те, чи перевозить він товар, ввезення якого заборонене даною державою, але без права заборони транзиту цього товару. Ці формальності не можуть викликати ні огляду товару, ні уповільнення транзиту. За подання неправильної декларації капітан чи судновласник підлягає відповідальності за законами держави, якій була зроблена декларація. Якщо Дунай є кордоном між двома державами, то судна, плоти, пасажири і транзитний товар звільняються при проходженні по річці від усіх митних формальностей (ст. 27).

При розгляді питань щодо транзиту необхідно пригадати також, що завдяки виходу суден через морські та річкові порти до міжнародних суднопотоків та перебування портів на перетині найкрупніших торговельних шляхів вже давно поставило перед світовим співтовариством питання правового регулювання транзиту через такі об'єкти. Намагання розробити систему регулювання транзиту не $\epsilon$ новими для практики міжнародних економічних відносин. Ще у 1921 році було підписано Барселонську конвенцію та Статут про свободу транзиту [23], що проголосила недискримінаційний принцип при його застосуванні, а також встановлення розумних тарифів. Згідно з Преамбулою цієї Конвенції, держави-учасниці мають намір «проголосити право вільного транзиту та здійснити регулювання 
такого транзиту в якості одного з найкращих способів розвитку співпраці між державами». Це положення, проте, не витікає зі ст. 6 Статуту, та не розглядається як норма міжнародного права, що застосовується й до держав, які не є учасницями Барселонської конвенції. Дійсно, зі змісту ст. 6 слідує, що держави-учасниці не зобов'язані надавати вільний транзит будь-якій іншій державі, за виключенням випадку, коли «однією з зацікавлених державучасниць надані переконливі доводи» на користь такого транзиту. Транзит надається не безоплатно, але тарифи за транзит повинні бути, згідно зі ст. 4 Статуту, «розумними» (reasonable). Згідно зі ст. 2 Статуту, держави-учасниці зобов'язані сприяти вільному транзитові залізничними та водними шляхами, що є зручними для міжнародного транзиту. Вони мають право вжити заходів забезпечення безпеки шляхів, засобів зв'язку та інших своїх інтересів, що відносяться до транзиту (ст. 5 Статуту). Ст. 3 Статуту передбачає, що крім зборів для покриття видатків на управління та нагляд у зв'язку із транзитом, держави-учасниці не повинні та не мають права встановлювати будь-яких спеціальних зборів за транзит. Проте залишається відкритим питання про те, чи можливо вважати ці зафіксовані у Барселонській конвенції 1921 року юридичні приписи звичаєвими нормами сучасного міжнародного права та у цій якості застосовними до будь-якого транзиту, у т.ч. до такого, за якого пересікаються не лише державні кордони, але й розмежувальні лінії між континентальними шельфами. Учасники Конвенції та Статуту про транзит зобов'язуються полегшувати свободу транзиту на своїй території, проте, вона гарантується лише «шляхами, відкритими для експлуатації та пристосованими до міжнародного транзиту», - $з$ останнього слідує, що можна закривати певні шляхи транзиту. Неприпустимими є мита, що стягуються «через транзит», тобто мають суто транзитний характер, а не обумовлюються будь-якими іншими обставинами, що супроводжують транзит. Можливим $є$ стягнення мита, що призначене на покриття видатків 3 управління та нагляду, що викликані транзитом. Воно повинне встановлюватися на засадах рівності, але можуть бути неоднаковими за своїми розмірами, відповідно до розмірів видатків на різних шляхах та можуть навіть не стягуватися взагалі. Останнє, очевидно, робить можливим й диференціювання обкладення, залежно від шляху слідування вантажу, полегшуючи транзит в одному напрямку та утруднюючи в іншому.

Висновки. Сучасне публічне адміністрування режиму судноплавних рік формується на підставі правових стандартів різного рівня, природно «виходить» за межі державних кордонів, базуючись на всесвітніх та регіональних міждержавних угодах, i національному законодавстві прибережних держав, що має відповідати стандартам обов'язкових для них міжнародних інструментів. Інституційний механізм такого адміністрування також не обмежується національними органами публічної адміністрації, а охоплює наддержавні інституції - річкові комісії. Правові стандарти такого адміністрування втілено у блоці угод, що присвячено окремим річковим 
комунікаціям, та сконцентровано на основних, найбільш вагомих, його аспектах: безпека та свобода судноплавства, адміністративні формальності, свобода транзиту та обмеження плавання військових кораблів.

\section{Jimepamypa:}

1. Україна розпочала головування у Стратегії $\mathrm{CC}$ для Дунайського регіону. Укрінформ. https://www.ukrinform.ua/rubric-polytics/3340423-ukraina-rozpocala-golovuvannau-strategii-es-dla-dunajskogo-regionu.html

2. Україна вперше за 70 років очолить комісію, що регулює судноплавство на Дунаї. Экономическая правда. https://www.epravda.com.ua/rus/news/2020/12/11/669086/

3. Конвенция о режиме судоходства на Дунае. Дунайская Комиссия. https://danubecommission.org/extranet/e-archive/convention-ru.pdf

4. Дунайская Комиссия. Дунайская Комиссия. https://cutt.ly/wU4SYOY

5. Угода про асоціацію між Україною, з однієї сторони, та Європейським Союзом, Європейським співтовариством 3 атомної енергії і їхніми державами-членами, 3 іншої сторони від 27.06.2014 р. Офіційний вісник України. 2014. № 75. Т. 1. Ст. 2125.

6. Про внутрішній водний транспорт. Закон України від 03.12.2020 p. № 1054-IX. Офіційний вісник України. 2021. № 4. Ст. 201.

7. Про державний кордон України. Закон України від 04.11.1991 p. № 1777-XII. Верховна Рада України. Законодавство України. https://zakon.rada.gov.ua/laws/show/1777-12

8. Convention and Statute on the Regime of Navigable Waterways of International Concern Barcelona, 20 April 1921. League of Nations Treaty Series. 2021. Vol. VII. P. 35.

9. Угода між Кабінетом Міністрів України і Урядом Республіки Хорватія про судноплавство на внутрішніх водних шляхах від 16.04.2004 р. Офіційний вісник України. 2007. № 2. Ст. 86.

10. Угода між Урядом України та Урядом Федеративної Республіки Німеччина про судноплавство на внутрішніх водних шляхах від 14.07.1992 р. Офіційний вісник України. 2006. № 41. Ст. 2774.

11. Угода між Кабінетом Міністрів України і Урядом Республіки Білорусь про судноплавство внутрішніми водними шляхами від 06.02.1998 р. Офіційний вісник України. 2010. № 74. Ст. 2655.

12. Плачкова Т.М. Адміністративно-правове забезпечення безпеки мореплавства в Україні. Дис. ... Д-ра філософії. Одеса, 2020. 216 арк.

13. 2011 год. Крушение теплохода «Булгария» на Волге. Круизинформ. http://cruiseinform.ru/cruisepedia/crash/krushenie-teplokhoda-bulgariya

14. Стан безпеки судноплавства та аварійності на водному транспорті в Україні (у тому числі і за ії межами, але із українськими суднами), включаючи маломірні (малі) судна, за перше півріччя 2021 року 3 наростаючим підсумком. Державна служба морського та річкового транспорту України. https://marad.gov.ua/storage/app/sites/1/uploaded-files/06072021/Zvit_ 1pivrich_2021.pdf

15. Правила судноплавства на внутрішніх водних шляхах України, затв. наказом Міністерства транспорту України від 16.02.2004 p. № 91. Верховна Рада України. Законодавство України. https://zakon.rada.gov.ua/laws/show/z0872-04

16. Положення про порядок видачі посвідчення судноводія торговельного судна, яке допущено до плавання судноплавними річковими внутрішніми водними шляхами, затв. наказом Міністерства інфраструктури України від 07.10.2014 р. № 490. Верховна Рада України. Законодавство України. https://zakon.rada.gov.ua/laws/show/z1324-14

17. Котова М. В. Современные принципы правового регулирования судоходства на международных реках Европы. Пробелы в российском законодательстве. 2015. № 3. С.187-190. 
18. Международное публичное право / отв. ред. К.А. Бекяшев. Москва: ТК Велби, Проспект, 2005. 460 с.

19. Кузнецов С. О., Аверочкіна Т. В. Морське право. Одеса: Фенікс, 2011. 382 с.

20. Гуреев С. А., Тарасова И. Н. Международное речное право. Москва: Международные отношения, 1993. 240 с.

21. Тарасенко Е. И. К вопросу мониторинга законодательного регулирования трансграничных рек. Евразийская интеграция: экономика, право, политика. 2010. № 8. C. $160-164$.

22. The Helsinki Rules on the Uses of the Waters of International Rivers, 1966. International Water Law Project. https://www.internationalwaterlaw.org/documents/intldocs/ILA/ILAHelsinkiRules1966-as_amended.pdf

23. Convention and Statute on Freedom of Transit, 1921. University of Oslo. The Faculty of Law. https://www.jus.uio.no/english/services/library/treaties/09/9-04/freedom-transit-statut.xml

\section{References:}

1. Ukraina rozpochala holovuvannia u Stratehii YeS dlia Dunaiskoho rehionu [Ukraine has started its presidency of the EU Strategy for the Danube Region]. Ukrinform. Retrieved from https://www.ukrinform.ua/rubric-polytics/3340423-ukraina-rozpocala-golovuvanna-u-strategii-esdla-dunajskogo-regionu.html [in Ukrainian].

2. Ukraina vpershe za 70 rokiv ocholyt komisiiu, shcho rehuliuie sudnoplavstvo na Dunai [For the first time in 70 years Ukraine will head a commission that regulates navigation on the Danube]. Jekonomicheskaja pravda - Economic truth. Retrieved from https://www.epravda.com.ua/rus/news/2020/12/11/669086/ [in Ukrainian].

3. Konvencija o rezhime sudohodstva na Dunae [Convention concerning the Regime of Navigation on the Danube]. Dunajskaja Komissija - Danube Comission. Retrieved from https://danubecommission.org/extranet/e-archive/convention-ru.pdf [in Russian].

4. Dunajskaja Komissija [Danube Comission]. Dunajskaja Komissija - Danube Comission. Retrieved from https://cutt.ly/wU4SYOY [in Russian].

5. Uhoda pro asotsiatsiiu mizh Ukrainoiu, z odniiei storony, ta Yevropeiskym Soiuzom, Yevropeiskym spivtovarystvom $\mathrm{z}$ atomnoi enerhii i yikhnimy derzhavamy-chlenamy, $\mathrm{z}$ inshoi storony vid 27.06.2014 r. [Association Agreement between the European Union and its Member States, of the one part, and Ukraine, of the other part from June 27, 2014]. Ofitsiinyi visnyk Ukrainy - Official Bulletin of Ukraine, 75, 1, 2125 [in Ukrainian].

6. Zakon Ukrainy "Pro vnutrishnii vodnyi transport”: vid 03 hrudnia 2020 roku. № 1054-IX [Law of Ukraine “On inland water transport” from December, 3, 2020, № 1054-IX]. Ofitsiinyi visnyk Ukrainy - Official Bulletin of Ukraine, 4, 201 [in Ukrainian].

7. Zakon Ukrainy "Pro derzhavnyi kordon Ukrainy": vid 04 lystopada 1991 roku № $1777-$ XII [Law of Ukraine "On the state border of Ukraine” from November, 4, 1991, № 1777-XII]. zakon.rada.gov.ua. Retrieved from https://zakon.rada.gov.ua/laws/show/1777-12 [in Ukrainian].

8. Convention and Statute on the Regime of Navigable Waterways of International Concern Barcelona, 20 April 1921. League of Nations Treaty Series. 2021. Vol. VII. P. 35.

9. Uhoda mizh Kabinetom Ministriv Ukrainy i Uriadom Respubliky Khorvatiia pro sudnoplavstvo na vnutrishnikh vodnykh shliakhakh: vid 16 kvitnia 2004 roku [Agreement between the Cabinet of Ministers of Ukraine and the Government of the Republic of Croatia on inland waterway navigation from April, 16, 2004]. Ofitsiinyi visnyk Ukrainy - Official Bulletin of Ukraine, 2007, 2, 86 [in Ukrainian].

10. Uhoda mizh Uriadom Ukrainy ta Uriadom Federatyvnoi Respubliky Nimechchyna pro sudnoplavstvo na vnutrishnikh vodnykh shliakhakh: vid 14 lypnia 1992 roku [Agreement between the Government of Ukraine and the Government of the Federal Republic of Germany on Inland Navigation from July, 14, 1992]. Ofitsiinyi visnyk Ukrainy - Official Bulletin of Ukraine, 2006, 41, 2774 [in Ukrainian]. 
11. Uhoda mizh Kabinetom Ministriv Ukrainy i Uriadom Respubliky Bilorus pro sudnoplavstvo vnutrishnimy vodnymy shliakhamy: vid 06 liutoho 1998 roku [Agreement between the Cabinet of Ministers of Ukraine and the Government of the Republic of Belarus on Inland Waterway Navigation from 6, February, 1998]. Ofitsiinyi visnyk Ukrainy - Official Bulletin of Ukraine, 2010, 74, 2655. [in Ukrainian].

12. Plachkova, T.M. (2020). Administrative Legal Provision of Maritime Safety in Ukraine. . Dissertation for the degree of Doctor of Philosophy in specialty 081 - "Law". National University "Odessa Law Academy". 216. [in Ukrainian].

13. 2011 god. Krushenie teplohoda "Bulgarija" na Volge [2011. The wreck of the ship "Bulgaria" on the Volga]. Kruizinform - Cruise information. Retrieved from http://cruiseinform.ru/cruisepedia/crash/krushenie-teplokhoda-bulgariya [in Russian].

14. Stan bezpeky sudnoplavstva ta avariinosti na vodnomu transporti v Ukraini (u tomu chysli i za yii mezhamy, ale iz ukrainskymy sudnamy), vkliuchaiuchy malomirni (mali) sudna, za pershe pivrichchia 2021 roku z narostaiuchym pidsumkom [The state of safety of navigation and accidents on water transport in Ukraine (including abroad, but with Ukrainian vessels), including small (small) vessels, in the first half of 2021 with cumulative results]. Derzhavna sluzhba morskoho ta richkovoho transportu Ukrainy - State Service for Maritime and River Transport of Ukraine. Retrieved from https://marad.gov.ua/storage/app/sites/1/uploaded-files/06072021/ Zvit_1pivrich_2021.pdf [in Ukrainian].

15. Pravyla sudnoplavstva na vnutrishnikh vodnykh shliakhakh Ukrainy, zatverdzheni nakazom Ministerstva transportu Ukrainy vid 16 lutoho 2004 roku № 91 [Rules of navigation on inland waterways of Ukraine, approved by the order of the Ministry of Transport of Ukraine from February, 16, 2004, № 91] zakon.rada.gov.ua. Retrieved from https://zakon.rada.gov.ua/ laws/show/z0872-04 [in Ukrainian].

16. Polozhennia pro poriadok vydachi posvidchennia sudnovodiia torhovelnoho sudna, yake dopushcheno do plavannia sudnoplavnymy richkovymy vnutrishnimy vodnymy shliakhamy, zatverdzheny nakazom Ministerstva infrastruktury Ukrainy vid 07 zhovtnia 2014 roku № 490 [Regulations on the procedure for issuing a certificate of a master of a merchant vessel, which is allowed to sail on navigable river inland waterways, approved. by the order of the Ministry of Infrastructure of Ukraine from 7, October, 2014 № 490]. zakon.rada.gov.ua. Retrieved from https://zakon.rada.gov.ua/laws/show/z1324-14 [in Ukrainian].

17. Kotova, M.V. (2005). Sovremennye principy pravovogo regulirovanija sudohodstva na mezhdunarodnyh rekah Evropy [Modern principles of legal regulation of navigation on international rivers in Europe]. Probely v rossijskom zakonodatel'stve - The Gaps in the Russian legislation, 3, 187-190 [in Russian].

18. Bekjashev, K.A. (2005) (Ed.). Mezhdunarodnoe publichnoe parvo [International public law]. Moscow: TK Velbi, Prospekt, 460 [in Russian].

19. Kuznetsov, S.O., Averochkina, T.V. (2011). Morske pravo [Law of the sea]. Odesa: Feniks, 382 [in Ukrainian].

20. Gureev, S.A., Tarasova, I.N. (1993). Mezhdunarodnoe rechnoe pravo [International river law]. Moscow: Mezhdunarodnye otnoshenija, 240 [in Russian].

21. Tarasenko, E.I. (2010). K voprosu monitoringa zakonodatel'nogo regulirovanija transgranichnyh rek [On the issue of monitoring the legislative regulation of transboundary rivers]. Evrazijskaja integracija: jekonomika, pravo, politika - Eurasian integration: economics, law, politics, 8, 160-164 [in Russian].

22. The Helsinki Rules on the Uses of the Waters of International Rivers, 1966. International Water Law Project. Retrieved from https://www.internationalwaterlaw.org/documents/intldocs/ ILA/ILA-HelsinkiRules1966-as_amended.pdf

23. Convention and Statute on Freedom of Transit, 1921. University of Oslo. The Faculty of Law. Retrieved from https://www.jus.uio.no/english/services/library/treaties/09/9-04/freedomtransit-statut.xml 